\title{
BAHASA DI BALIK PEMBUNUHAN KARAKTER: STUDI KASUS RUMOR LARANGAN HIJAB BAGI PEGAWAI BUMN
}

\author{
Prihantoro \\ FIB Universitas Diponegoro \\ email: prihantoro2001@yahoo.com
}

\begin{abstract}
Abstrak
Artikel ini menyajikan analisis wacana mengenai larangan hijab yang memberikan stigma negatif pada Menteri BUMN. Sumber data berasal dari cuitan DE dan artikel surat kabar NS yang mengutip DE. Data dianalisis dengan model framing Pan dan Kosicki yang dikaji oleh Borah (2011) dan teori lain yang relevan. Hasil analisis menunjukkan bahwa citra negatif berawal dari cuitan DE. Hal itu terjadi karena pergeseran struktur nomina bare noun dari indefinit menjadi generik dapat menyebabkan sebuah generalisasi yang salah (sesat pikir). Penanda visual (huruf tebal, tanda merah), pemilihan kutipan, dan penekanan lainnya tampak seperti foregrounding yang diarahkan untuk pencitraan negatif orang tertentu. Fakta tersebut dapat menjadi dasar untuk meragukan keaslian dokumen yang diupload DE. Meskipun referensi dilakukan secara eksoforis (tidak tertulis di teks), pembaca tidak kesulitan memahami isi wacana dengan menghubungkan struktur wacana dan informasi yang ada.
\end{abstract}

Kata kunci: bare noun, generik-definit-indefinit, ambiguitas, foregrounding, hijab

\section{THE LANGUAGE BEHIND CHARACTER ASSASSINATION: A CASE STUDY OF RUMORS THAT SOE EMPLOYEES ARE PROHIBITED FROM WEARING VEILS}

\begin{abstract}
This article presents discourse analysis of veil wearing prohibition that gives negative stigma to the Minister of State-owned Enterprises (SOE). The data sources were DE's tweets and an article in the NS newspaper quoting DE. The data were analyzed by the framing model by Pan and Kosicki studied by Borah (2011) and other relevant theories. The results of the analysis show that the negative image comes from DE's tweets. This occurs because of a shift in the nominal structure of an indefinite bare noun into a generic one, resulting in a false generalization (syllogistic fallacy). Visual signs (bold letters, red marks), quotation selection, and other emphases seem to foreground and lead to a particular person's negative image. Such a fact can be used as a basis to doubt the originality of the document DE uploaded. Although the reference is exophoric (not written in the text), readers do not find it difficult to comprehend the discourse contents by relating the discourse structure to the available information.
\end{abstract}

Keywords: bare noun, generic-definite-indefinite, ambiguity, foregrounding, veil

\section{INTRODUCTION}

In the middle of December 2014, a malicious rumor about recent Indonesian minister of BUMN (State Owned
Enterprises), Rini Soemarmo (RS) was circulating among mass and social media that she had issued a regulation that banned BUMN employee to wear hijab. 
Hijab, or jilbab, is a veil-like outfit that is an attribute of female muslim.

Although later proven to be completed unfounded, the rumor went viral on social media. People sharing the rumor link their statuses or comments to an on-line article published by a small-scale newspaper, Non-Stop (NS). NS created the image of BUMN minister as an anti-Islam and claim the validity of their news from a tweet under the account name of DE, which is affiliated to an opposition party.

Although it is proven to be a prevaricated news, what needs further examination is how some people at that period of time easily believe the rumor to be true. The answer is twofold: the way the texts interrelatedand presented by the author, and the less-critical reading by the reader.

Linguistics here plays a central role, as it might be the source of fallacies (Hurley, 2012). On one side, linguistics is not to blame solely as it only projects author's rhetoric and intent. On the other side, authors may also recreate realities in different ways.Some information is backgrounded, while some others are foregrounded. Sometimes, information is not presented completely and texts might be organized in a way that assassinates one's character. At this point, readers cannot just rely on texts and author's honesty anymore.

This research significance is to make people aware that reading texts critically is important: both on the linguistic structures and situational contexts. Texts, realities, and author intents are one integrated entity. Taking a text for granted, without critically reviewing it might lead readers to false conclusion(s).

The texts I analyze here are: 1) NS article concerning no-hijab policy by the Minister of BUMN (December 16, $2014), 2$ ) the summary of DE's tweets which focus on this rumor, and 3) the document that DE claimed to support her arguments. The tweets may be consisting of her solely, along with uploaded photo, or with responds from her followers. A series of analysis in this paper will show how NS and some readers took the inferencewrongly under the influence of the discourse structure built by the authors of the texts. The description will relate the discourse structure by the concept of genericity, definiteness, framing and markedness.

I here argue that reasons for the wrong inference may happen is the discourse structure of the texts, which is represented by 1) the narrative structure of NS article and DE's tweets, 2) the shift of BUMN from indefinite to generic, and 3) the anti-islam markingsas shown by the use of negative prosody words, graphical markings, and quotation preference.

As one of my points is about how readers generalize from details on the texts, I believe it is important to review the concepts of genericity and definiteness, and how they apply in Indonesian (Chung, 2000). Bare noun is mostly known to represent genericity, as in English and some other languages. In English, an article might be used to mark definiteness. However, article is a linguistic device that is not present in Indonesian language. See (1) and its gloss in English:

(1) Presiden telah menaikkan harga BBM

President have raise price oil

'the President hasraised the oil price'

As Porter (2005) suggested, In English, article 'the' must be present when the referent is definite.In (1) presidenrefers to only one particular president. See the VP 'raised the oil price', which does not apply to all presidents.

Now, observe the same bare noun presidenin (2). President in (1) and (2) are all bare nouns. However, presiden in (1) is definite [+DEF], while presiden in (2) is generic $[+\mathrm{GEN}]$. 
(2) Presiden memimpin sebuah negara

President lead one country

'President leads a country'

In (2), presiden is generic as the VP'leads a country' holds true for all presidents. On the contrary, VP in (1) might hold true only for some presidents (the one(s) who raised the oil price); it does not apply to all presidents. The question now is, how can a bare noun be definite in Indonesian? How can Indonesian speakers distinguish that presiden is definitein (1) and generic in (2)?

The answer is the relevant contexts and the background knowledge of the readers. When readers are faced with sentence in (1), for instance a headline, they process the linguistic structure; and when faced with ambiguities, they will confirm the meaning of the bare noun with realities and theirbackground knowledge. For instance, I have the knowledge that President Jokowi (Joko Widodo, The $7^{\text {th }}$ and current president of Indonesia) announced that the government officially reduced the subsidy for the oil price. This information will validate my decision to determine the bare noun in (1) as definite. When this information is present, readers will always try to relate this to the event happening in the shortest timeframe. This is parallel to the findings of some studies that people will psychologically relate events that happen closelyin time as one sequence.

When encountering (1), I will not refer to the previous president SBY(Susilo Bambang Yudhono) although he also did an exactly same thing. This is because, it happened weigh more distance in the past. Instead, I will refer to the current president, Jokowi as it is shorter in distance.

This implies that bare noun in Indonesian is processed covertly with high-context. See (Chung, 2000). The same phenomenon also applies in Malay (Carson, 2000) and Javanese
(Asmaramurthi, 2008), where null subject or bare noun can also be definite with proper discourse context.). This is quite different from languages like English when definiteness is processed with lowcontext (overt linguistic marker).

The consequence of the high-context processing is that it relies heavily on the realities and speaker-reader knowledge where the knowledge may vary from person to person. This spot may lead to different interpretationsamong readers. Say, when I am not aware of the information that recent Indonesian president, Jokowi, has raised the oil price, I might resort the bare noun presiden to indefinite, and then raise a question; 'which president?' or 'is this president Jokowi?' or 'is this the previous president?' when I understand the bare noun definitely.

\section{(3) Presiden telah menaikan harga $B B M$ \\ Presiden have raised price oil \\ 'a President has raised the oil price'}

A bare noun in Indonesian, depending on the context, might be generic, definite or indefinite. However, often a false deduction can happen even with a clear definite marker. This often involves ideology, which is part of readers' knowledge. Consider (4):

(4) The terrorist is an Arab

(5) All Arabs are terrorists

It is clear that the definite marker 'the' , which attaches to 'terrorist', implies that it is a person in particular. The predicate 'an Arab' describes his/her nationality. However, people with an anti-arab ideology often jump to the conclusion that all Arabs are terrorists (5) without any prior critical reading. The decision might also happen as the person is always exposed to the visual markings showing only terrorists from Arabic/ middle east countries. The decision might 
be different when people were exposed to multi-national terrorists news, with the appearance that resembles Caucasians, Africans or East Asians, for example. Therefore, to understand a text objectively, the linguistic of the text solely is not sufficient.

Now, I will reviewhow markedness can also contribute to the data I discuss here. However, I want to make myself clear first that markedness here is defined by pragmatics or discourse studies (Tran, 2002) because it is also a widely used term in other subfields of linguistics such as phonology, morphology and syntax (Eckman, Moravcsik, \& Wirth, 1986). The term marking here is equal to foregrounding that is used in semiotics or framing analysis model.

One function of marking is to show that it is against the stereotype. The phrase 'female doctor' might be uncommon in the past as most doctors were male. Therefore, marking a doctor as female wasnecessary; otherwise, people will jump to the conclusion that the doctor is a male. These days, of course people would just say doctor to refer to both male and female doctors.

Another function of marking is for emphasis or focus (Sinclair, 2003). When someone goes to a hospital to see an OB/GYN specialist, in the registrar, she mightask the nurse 'can I have afemale doctor to examine me? There, doctor is marked by 'female' not because the doctor is male in stereotype, but to emphasis her preference, for instance, to examineherprivate reproduction organ. Marking can also be performed by graphics such as highlight, boldfaced fonts or italic. In the paper, I will show later how DE marked the text with Islamic attributes like jilbab 'hijab' and jenggot 'beard'. In communication studies, this approach is known as framing analysis. In this research, I applied Pan and Kosicki's model as studied by Borah (2011).

\section{METHOD}

The procedure of data collection and analysis are as follow: (a) downloading DE tweets and NS article that concern no-hijab policy rumor as primary source of data; (b) downloading supporting documents (news articles that quote DE tweets, responses to DE tweets, images etc); (c) investigating the bare noun structures of DE tweets in terms of genericity and definiteness; (d) identifying the noun structures that mislead readers to no-hijab policy generalization, and (e) identifying discourse structures and markings/ foregroundingon the discourse that lead to creation of the negative image

My analysis focuses on how NS organized its article such as the preference of the headline, sub-headline, quotation, and the content of the article. As for the tweets, I analyzed both the tweets and the supporting documents. In analyzing the discourse structure, I describe the grounds for my arguments that: 1) the tweet from DE has created an anti-Islam image by movement from indefinite to generic structure to create a false generalization; 2) the negative evaluation was prescribed by both DE tweets and NS article under the preference of negative prosody/polarity words or lexicogrammar construction and also the discourse structure; 3 ) the markedness and foregrounding on the supporting documentscreates the impression that BUMNs recruitment avoid 'good muslims' and welcome 'people with criminal mark'. I also explored how DE's responsive tweets after NS news discovered to be fake resembles 'test the water' protocol.

\section{FINDINGS AND DISCUSSION}

Findings and discussions are divided into two sub-sections 1) DE tweets, and 2) NS Headlines and articles. 


\section{DE's Initial Tweet: The Source of the Problem}

Sharing fake news on social media (facebook, twitter, personal blog) is not a new phenomenon as studied by Marchi (2012). In her study, she concludes that sharing artificial information is a form of rejectionto the objectivity of journalistic products. Either reading from social media or journalistic product, by the end, It is the reader who has to be critical by not taking for granted of what is presented.

In this sub-section, I present DEtweets, which are the sources of the problem. Thedata is presented with the support of image(s). See her first tweet, which is also quoted by NS:

(6) Kriteria rekrutmen sebuah BUMN per 2014

'Recruitment Criteria of a BUMN per $2014^{\prime}$

- Kriteria rekruitmen sebuah BUMN per 2014

cc@SangPemburu99@hafidz_ary@malakmalakmal@fahiraidris

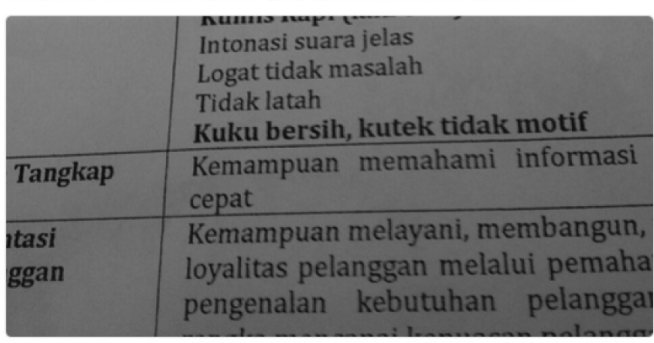

She claimed that the picture she uploaded is an assessment sheet for a series of a BUMN recruitment test, although many still doubt the originality of this document.

In (6), BUMN is not definite but indefinite. It is marked by sebuah 'one', which is an indefinite quantifier in Indonesian. The consequence of using indefinite quantifier (not only in Indonesian but also in English) is the raise of suspicion, as it mentions one among many, but does not specify it. Imagine when you hear 'there is a traitor among those ten people'. You will start to check on each person, and make a guess of who the traitor is. However, your guess can be wrong. It also applies here. The suspicion may resort people to infer wrong BUMN.

\section{Graphical Marking and the Shift to Generic Noun}

In this sub-section, I discuss the supporting document, which is a text in image format, which DE uploaded. She claimed that it is the photo of an assessment sheet for a BUMN recruitment test (see 6 and picture 1) and the photo was marked (by her or by someone else) by boldfaced and red marks. In markedness theory, information might beforegroundedon what the author believes to beessential information. See (Harris in Diaz, 2011), Eckman, et al, 1986, and Tran, 2002). According to the Pan and Kosicki's framing model, as discussed by Borah (2011),boldfacing or color marking on certain lexical items is the application of framing that works on graphic level.

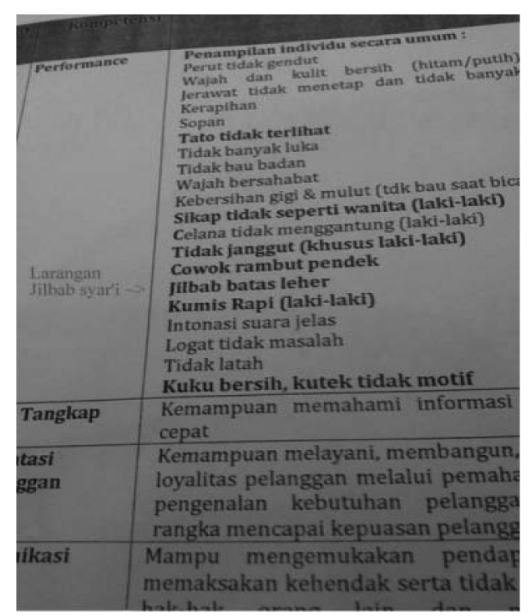

Picture 1. A More Complete Fragment of the so called Assessment Sheet

The boldfaced requirements lead to restraining attributes thatsignify a good male/female muslim. The negation is shown by grammatical or lexicalized negator. See underlined as in jilbab batas leher 'hijab's must not cover the neck' and 
tidak janggut 'no beard'. DE also marked larangan jilbab syar'i by red marks. Above the no-beard policy, a phrase is not fully boldfaced. It says celana tidak menggantung 'trousers must not be above the heel'. See picture 1.

The strategy is to use negation to modify noun. Here we see hijab, which is positive in meaning, and also janggut 'beard' (neutral in meaning). The polarity becomes negative when negation tidak 'not' is used to modify the words.

The use of negation, both grammatical or lexicalized, as well as the marking, is orchestrated to make muslim readers believe that the BUMN is not on the muslim side (Muslim is majority in Indonesia).

The term jilbab batas leher 'hijab must not cover the neck'. The question that we need to ask is what constitute a good hijab? A body and head cover that still shows the body shape (except face and hands), including the neck, is not hijab. Therefore, there is no such thing as jilbab syari (jilbab marked by syar'I 'rules') as she highlighted even though this term is widely used to refer to good hijab.

The term jilbab syar' $i$ is coined as some muslim females use a hijab-like outfit that still shows their body texture such as breasts, thigh, buttocks etc.

As for beard, there are some hadits (prophet's words) which suggest male muslims to grow it. Some still debate whether this must be understood literally or contextually. The same thing goes for the trousers' rule.

While DE's comment on assessment sheet applied indefinite quantifier, DE failed to maintain her consistency on her next tweet:

(7) Saudaraku yg berjenggot. Nggak usah repot-repot daftar jadi pegawaipemerintah/ BUMN ya. Tidak bakal diterima!

'brothers with beard. Do not waste your time applying for civil servants or
BUMN employee. You will definitely be rejected'

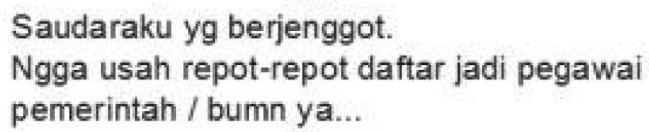

Tidak bakal diterima!

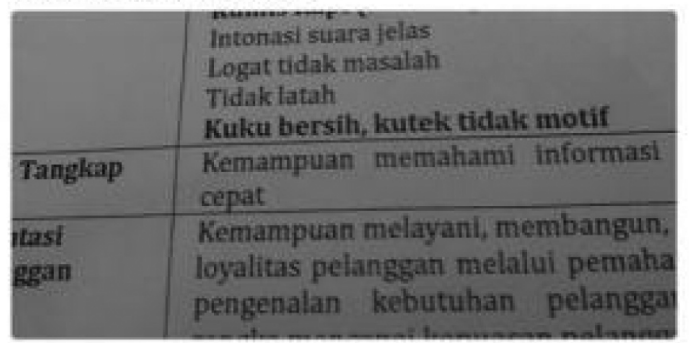

Picture 2. Shift from Indefinite to Generic

Fundamentally, DE shifted the noun from indefinite to generic; from one BUMN to all BUMN and all government institution or pegawai pemerintah 'civil servants' (See picture 2 and Table 2). This implies that she gradually shifts from accusing one particular BUMN to all BUMNs and all government institutions as well.

While creating the image of anti-islam, DE polished herself as pro-Islam by the use kinship address that implies in-group identity (Brown \& Levinson, 1987). The tweet is marked by the kinship address term saudaraku (7) 'brothers and sisters', addresses of people with related ideology (including muslim), which shows in group identity.

Anyone who disagrees to this tweet is excluded from her in-group identity, as for this 'good muslims' base. Pan and Kosicki believe that In order to support an ideological claim, certain lexical items or phrases might be emphasized. DE here employed Islamic ideology to strengthen his generalization. See how the text creates BUMN's negative image by the ideological marking in Table 3. 
Table 2. Semantic Values Shift from Indefinite to Definite

\begin{tabular}{lcc}
\hline \multicolumn{1}{c}{ Values } & $\begin{array}{c}\text { Sebuah } \\
\text { BUMN } \\
\text { 'a BUMN' }\end{array}$ & $\begin{array}{c}\text { BUMN/PEGAWAI } \\
\text { PEMERINTAH } \\
\text { 'BUMN/Civil Servants' }\end{array}$ \\
\hline [SINGLE SUBJECT] & + & - \\
[MULTIPLE & - & + \\
SUB]ECTS] & & - \\
[INDEFINITE] & + & + \\
[GENERIC] & - & + \\
\hline
\end{tabular}

Table 3. The Creation of Negative Image by Ideology Marking

\begin{tabular}{cc}
\hline I & Anti-Islam \\
D & celana tidak menggantung \\
E & 'trousers are not hanging above heels' \\
O & jilbab batas leher 'neck shaped hijab' \\
L & tidak janggut 'no beard' \\
O & Crime - Support \\
G & tato tidak terlihat \\
X & 'tattoo is hidden' \\
\hline
\end{tabular}

Some prophet's sayings recommend male muslims to grow beard and use trousers that do not cover heels (still debatable whether should be understood literally or contextually). Islam also requires that female wear hijab that does not show her body shape (except face and palm), which means not showing the neck as well. By forbidding the employee to do so,the image that the discourse creates is anti-islam. Focus on the markingsjilbab batas leher 'hijab must show the neck' for female, celana tidak menggantung 'trousers are not hanging above heels', and tidak janggut 'no beard' for male. hadits

While the previous foregrounding applies on what is forbidden, another foregrounding is on what is allowed. Besides the image of avoiding 'good muslim' to be BUMN employees, another image that it tries to create is BUMN prefers an individual of negative traits. Consider another line that it marked with boldfaced; tato tidak terlihat 'tattoo is well hidden'. Tattoo has long been considered as a feature closely related to crime, as it usually attaches to criminals (Barker, 1999).
Therefore, the marked part that 'tattoo is well hidden' entails that BUMN allows people with crime attribute, and as oppose, rejects 'good muslim'. The graphical markings are amplified by her own tweet: tidak bakal diterima! 'you will definitely be rejected!' with punctuation mark to emphasize a stress (Crystal, 2006).

\section{(8) Bertato boleh. Jilbab syar'I gak boleh} 'you may have tattoes. But a proper hijab is prohibited.

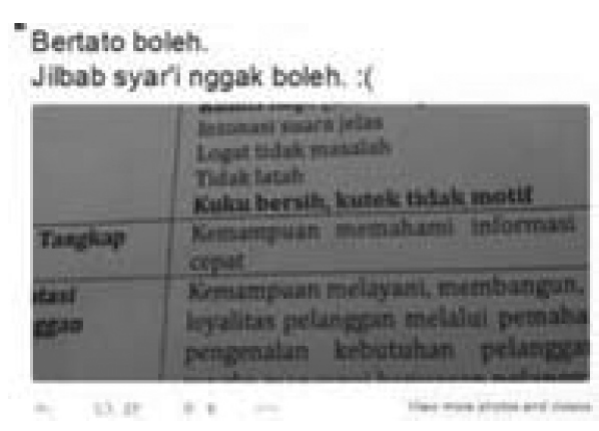

My suspicion that this document is fabricated goes stronger by the inconsistent diction or word choice. First, only one among all details here is written by nominalization kerapihan, where the normally used is the adjective rapih with no simulfix. This is quite inconsistent with the other details. Second, I also identified features of informal language such as contraction $t d k$ (for tidak 'no') and word choice cowok 'young male'. The silliest one is the inconsistence of using reference word for male. On one detail, it uses lakilaki while on the other, it uses cowok. The word cowok is the informal form of laki-laki or lelaki.

\section{'To Test the Water'}

According to Cambridge American Idiom Dictionary (Center, 2003), the phrase 'to test the water' means to float an idea; you propose something to understand how people might respond. In politic and communication, this term means to spread 
a thought about evaluation or about 'to do something' where it has future aspects. If the majority is silent, then the rumors will come true. However, if there are many rejections, then the ones who 'test the water' will respond to it evasively, saying that it is only a plan or thought. The evasive movement is usually by saying that 'this is only a plan, this is only a draft, this is not the final decision'.

(9) Sudah percaya kalau selama inibukan 'test the water'?

Now are you convinced that for all this time it is not 'test the water'?

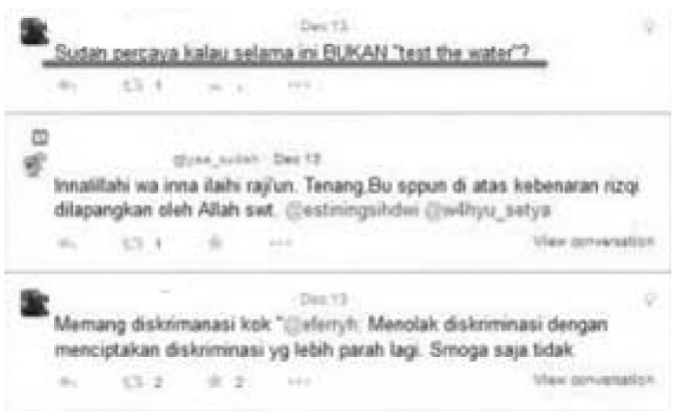

DE is questioning whether people believe that 'this' is 'test the water', after she presented the rumor in sequence. 'This' here refers to government policy. We can reveal DE's intent by means of speech act. In speech act, a particular speech act is not bound to a particular form. Even though in surface the form is a question, but it actually suggests more. This is a yes/ no question (where yes is the expected answer), but it is actually a statement that the no-hijab policy is not on the stage of testing the water anymore, but it is real and final.

One aspect about testing the water is 'playing save'. This seems to be her step, when some people start questioning the evidence. The news went viral and people were getting more and more suspicious. Some start questioning DE's version of BUMN assessment sheet as it resembles the requirement for storekeepers in
Alfamart and Indomaret, some franchised convenient stores in Indonesia. See her next tweet :

(10) Saya menaruh hormat kepada segenap pejabat penyelenggara Negara termasuk para menteri khususnya yang saya muliakan bu rini.

'I respect all government officials, including the ministers, particularly the one I honor, Bu Rini'

Saya menaruh hormat kepada segenap pejabat penyelenggara Negara termasuk para menteri khususnya yg saya muliaka Bu Rini.

The news went viral and finally DE made her clarification about her tweet. In (10) she mentioned that she respects all government officials (marked by quantifier segenap 'all'), and she marked them specifically by para mentri 'the ministers' and more specifically ' $B u$ Rini', who is the minister of BUMN.

It is interesting that she used the term clause saya muliakan 'I honor'. The clause here, introduces the object in a more specific detail. Mulia is an evaluative adjective to mention that the entity [+HUMAN] receiving this evaluation is honorable/noble; in other words, this is positive evaluation that came after the rumor be proven to be completely unfounded. By making it a verb (attaching suffix $-k a n$ ), the agent who performs this act also acknowledges that the entity is honorable. Here, she foregrounds her attitude toward the minister. But actually, this is only a background before her actual evasive movement:

(11) Saya TIDAK PERNAH menyebut MENTRI manapun dalam tweet saya. Bisa dicek.

'I HAVE NEVER mentioned any specific MINISTER in my tweets. Check it.' 
Saya TIDAK PERNAH menyebut MENTERI manapun dalam tweet saya. Bisa dicek.

\section{(12) Untuk Koran NonStop, saya tidak pernah berhubungan dengan Koran ini. 'for NonStop newspaper, I have never been in contact with this newspaper' \\ - Untuk Koran NonStop, Saya tdk pernah berhubungan dengan koran ini.}

In (11) she uppercased tidak pernah 'NEVER' and menteri 'MINISTER'. In netizen communication, this mark is equal to shouting and never used unless very important (Crystal, 2006). She says she has not mentioned any minister responsible for this act.

Implying a reference might be performed in different ways. It might be textual via anaphoric or cataphoric relation. However, people can make reference, even when the reference is not mentioned at all in the text, which is called exophoric relations (Huang, 2006). Unlike other referencing methods where the reference is mentioned in the text, exophora works on the contextual level, where text, readers' background knowledge and realities are equally important to interrelate.

In (12) she also confirmed that she has never been in contact with the newspaper, which is a clear violation of journalism ethics (Frost, 2014) for NS. We will discuss this later, and focus on DE's intent here.

When a text is created, the intent of an author is a determinant on how the text takes shape, as applied in a study by Diaz (2011) There are several possible intents. First is that she was sincere and honest with pure noble intention, and aimed only on a BUMN. But this is hard to believe as she, in her retweet generalized to all BUMNs and all government institutions (Picture 2). The second one, she targeted all BUMNs and all government institutions. This is another possible interpretation.
But if this is the case, then it does not make any sense to tweet evasively. Another possibility was that she did not target the minister of BUMN but she was expecting the minister's boss, who is the president of Indonesia. However, as she mentioned BUMN, then it unfortunately narrowed down to the minister of BUMN only. The generalization was not as completely as she was expecting. In this case, she was stacked in the middle. For this reason, she has no other choice but to do evasive scenario, which follows the same pattern of 'test the water'. Check the organization as shown in figure 1 :

Figure 1. The Organization of 'test the water'

A rumor is spread with an ambiguous interpretation

$>$ The rumor went viral

$>$ People took wrong generalization/ negatively

$>$ It is widely published in the media

$>$ Confirmation

If true

$>$ Keep provoking

If not

$>$ do evasive movement.

\section{NS Headline}

As I have commented previously, the rumor begins with DE's tweet and several online media (some have removed the links now). However, it became more viral as it became the headline of a local newspaper. See (13), which is the headline of a small-scale newspaper 'NON STOP' December the $16^{\text {th }} 2014$ (http://www. nonstop-online.com/2014/12/astagamenteri-bumn-larang-wanita-pakaijilbab-ke-kantor).

If we refer to DE tweets as in 11 and 12 , it is clear that at least two among many journalism ethics (Frost, 2014) are violated: confirmation and cover both sides. There is 
no contact/clarificationfrom DE and none also from the minister of BUMN, where these should have been done before the news is published. Nevertheless, NS put the article with provocative headline:

\section{(13) Astaga, Mentri BUMN Larang Wanita} Pakai Jilbab ke Kantor

'Oh My God, The Minister of BUMN banned females with hijab to go to the office'

(14) Astaga

'oh my god'

The word form astaga is an interjection, which is one of the markers of expressive speech act. The term expressive is used as this speech act represents the feeling of the speaker (or writer in this case). The semantic prosody of astaga is mostly negative.

This word is common among muslims. A muslim will say astaghfirullah (from Arabic) to respond to a surprise in which he/she believes that it is something negative. The word astaga might probably derive from this (Jones, 2007). The use of this arabic-loan-word creates the atmosphere of ideological similarity between NS and muslim readers, which Brown \& Levinson (1987) refer as sharing common ground. It gives the impression that NS sympathized over muslims.

Syntactically, the effect of the use of this word is not on the level of word or phrase, but the whole sentence.

\section{(15) Mentri BUMN Larang \\ Minister BUMN forbid}

The verb larang'to forbid' requires a human agent. This follows the concept of selectional restriction, where semantic fields of the lexical items must be parallel to avoid anomaly on combinatory (phrase/ sentence) level (Molinaro, Carreiras, \& Duñabeitia, 2012). Here the agent is Mentri BUMN.

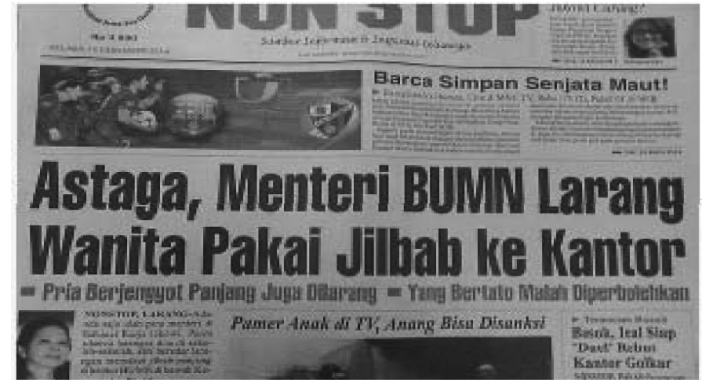

Unlike English, definiteness in Indonesian is not marked by article (Wijaya, 2012). The bare noun in Indonesian may suggest genericity or definiteness. Thus, Mentri BUMN might be generic or definite. When generic, it does not refer to any particular person. But the VP larang wanita berjilbab pergi ke kantor 'banned female with hijab to go to the office' indicates that this is not the common thing a minister does; hence, the NP mentri BUMN is definite. The minister (mentri) here, of course, is the agent that is syntactically responsible for the verb phrase. In short, this minister is the one to blame for any of the negative impact. We need sentence semantic to determine the semantic prosody of larang here, but actually the verb larang itself has the feature of lexicalized negation.

When appear in isolation, the connotation of larang is usually negative. we can see how the agent (RS) receives multiple negative evaluations from the exclamation astaga and the verb larang. I here follow Fairclough (2013), who believes that authors often use evaluation languages to transfer their thoughts and ideologies.

(16) Wanita Memakai Hijab Pergi ke Kantor Female wear Hijab go to office

The headline, as overall, suggests antimuslim thought, addressed to the minister of BUMN.

A relative clause in (16) is introduced by the verb larang. This is a clause embedded to the verb larang as its object 
(grammatically). In its syntax-semantic role, this clause is the theme, where it is the entity affected by the action of the agent. The subject of this embedded clause is wanita memakai hijab 'female to wear hijab'. Wearing hijab is something obligatory for female muslims. However, this action is negated by larang which makes the prosody negative.

In conclusion, the minister forbids something, which is believed by muslims to be the words of Allah (muslim's god). The message is now clear: the minister defies muslim god's law.As for linguistic perspective, the phrase pergi ke kantor has multiple interpretations.

Syntax here is often the source of structural ambiguity (Hurley, 2012). But in newspaper headlines, this is a common phenomena as some language elements are omitted (Marcoci, 2014). However, most readers will always generalize for the reasons that 1) bare noun of kantor allows generic interpretation, 2) situational contexts which involve the content of the article, and existing ideologies.

The verb phrase pergi ke kantor 'go to the office' here seems to require more contextual interpretation. The verb phrase is composed of the verb pergi 'to go', and prepositional phrase ke kantor (the preposition ke is followed by a goal kantor 'office'). The problem here the co-text does not suggest whether kantor is generic or definite. When kantor is defined in generic terms, she forbids any female wearing hijab to go to ANY office. So, if the goal of the travel is to a place called ' $k a n t o r$ ', then it is forbidden. So, is it definite? When we say that kantor here is definite, another question shall arise. Is it the office that is owned by the females with hijab? Is it the office where they work? Where they want to pick up someone? Different possibilities may arise as a result of the ambiguity.

As it has been commented previously, DE shifted BUMN from indefinite even generalized to all government institutions.
In between, someone asked about which BUMN she meant. This implies that someone realized the indefiniteness and to end suspicion, DE must make it definite by stating the name of the BUMN. However, DE refused to answer (17) and even generalized to all government institution. When asked to verify the BUMN she referred, DE refused vaguely, making people more suspicious.

\section{(17) Maaf belum bisa saya share}

Sorry, I can't share that yet

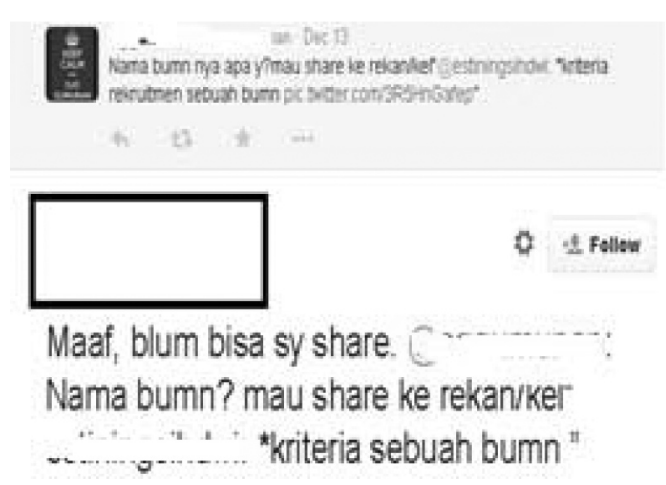

Some dedicated reporter question the quality of the article as it does not comply to some fundamental principles of journalism documented by Frost (2014) such as 'cover both sides' or 'verification'. The article was written one side (see DE's disclaimer on 11 that NS had no contact with her), and it does not mention any effort of requesting confirmation either from the user of DE account or from the BUMN official.

Most readers, however, are having no difficulty in determining to whom the anti-islam image is addressed,soon after they are exposed to the content of the article (or obtaining the information from other resources) and making exophoric reference to the realities outside the text (Huang, 2006). Up to this point, it is clear that the article published by NS is not a good journalistic product.

The next sub-section describes that discourse structure of the news article 
used by NS to convince readers that the news they fabricated is true.

\section{The Narrative Structure of NS Article}

What might lead people to believe the news article of NS is true as its narrative structure, or so called framing model as proposed by Pan and Kosicki (see Borah, 2011). It connects the rumor of the minister of BUMN that forbids hijab, with the previously existing news, where the Minister of Education, Anies Baswedan $(\mathrm{AB})$ has also been claimed to forbid muslim students pray in school. One of the religious preachers, Yusuf Mansur (YM), who is known for his business, believed this rumor to be true and even attacked $A B$ on twitter. But later he apologized to $A B$ as the rumor was also proven to be completelyunfounded (http://www. muslimedianews.com/2014/12/ustadzyusuf-mansur-akui-salah-dan.html).

The narrative begins by the headline and the sub headline. The headline is the rumor itself, while the sub headline covers support for people with negative traits (tattoo) and opposes people with positive traits inIslam(beard\& hijab). Tattoo here is negative in prosody as people often relates this to crime (Barker, 1999), whereas the origin of tattoo itself is to mark criminals (Caplan, 1997):

(18) Pria Berjenggot Panjang Juga Dilarang. Yang Bertato Malah Diperbolehkan

A long-bearded man is also forbidden but the man with tattoo is welcomed

The content itself is divided into two, the first one is about the no-hijab policy rumor, and the second one is about the no-prayer rumor, which has also been found to be completely unfounded. The two rumors, however, share something in common, that is the negative image (anti-islam) on the government. See the head of the second content, which aimed at the Minister of education:
(19) Doa Di Sekolah Pernah Dilarang Prayer in schools was forbidden

This is like wrapping a lie with another lie. For each rumor, the developmental sequence is almost the same. It elaborates the rumors with negative evaluation from prominent figures such as professionals (psychologist), politician (local senator), religious preachers (ustadz, habib), and activist (woman activist). This quoting strategy is parallel to Pan and Kosicki's framing model as discussed by Borah, (2011)

(20) Psikolog lulusan Universitas Gajah Mada (UGM) ini, menyuarakan keprihatinannya

The UGM graduated psychologist expressed her concern.

(21) Postingan larangan berjibab di kantor BUMN ini menarik perhatian putra Amien Rais, Hanafi Rais.

This no-hijab policy in BUMN news has attracted the son of Amin Rais, Hanafi Rais, to comment

(22) "katanya Ketua Komisi I DPR RI Mohammad Hanafi Rais, kemarin.

Said the head of Commission 1 of the house of the representatives, Mohammad Hanafi Rais yesterday.

(23) Pelarangan memakai Jilbab syar'i di kantor BUMN membuat geram sejumlah ulama. Salah satunya adalah Ustadz Agus Darmawan.

The no-hijab policy has upset some religious leaders. One of them is Ustadz Darmawan

(24) Habib Selon menilai larangan tersebut sangat melecehkan agama Islam.

Habib Selon believes that the rule harasses Islam 
Table 1. The Discourse Structure of No-Hijab Policy Rumor by NS

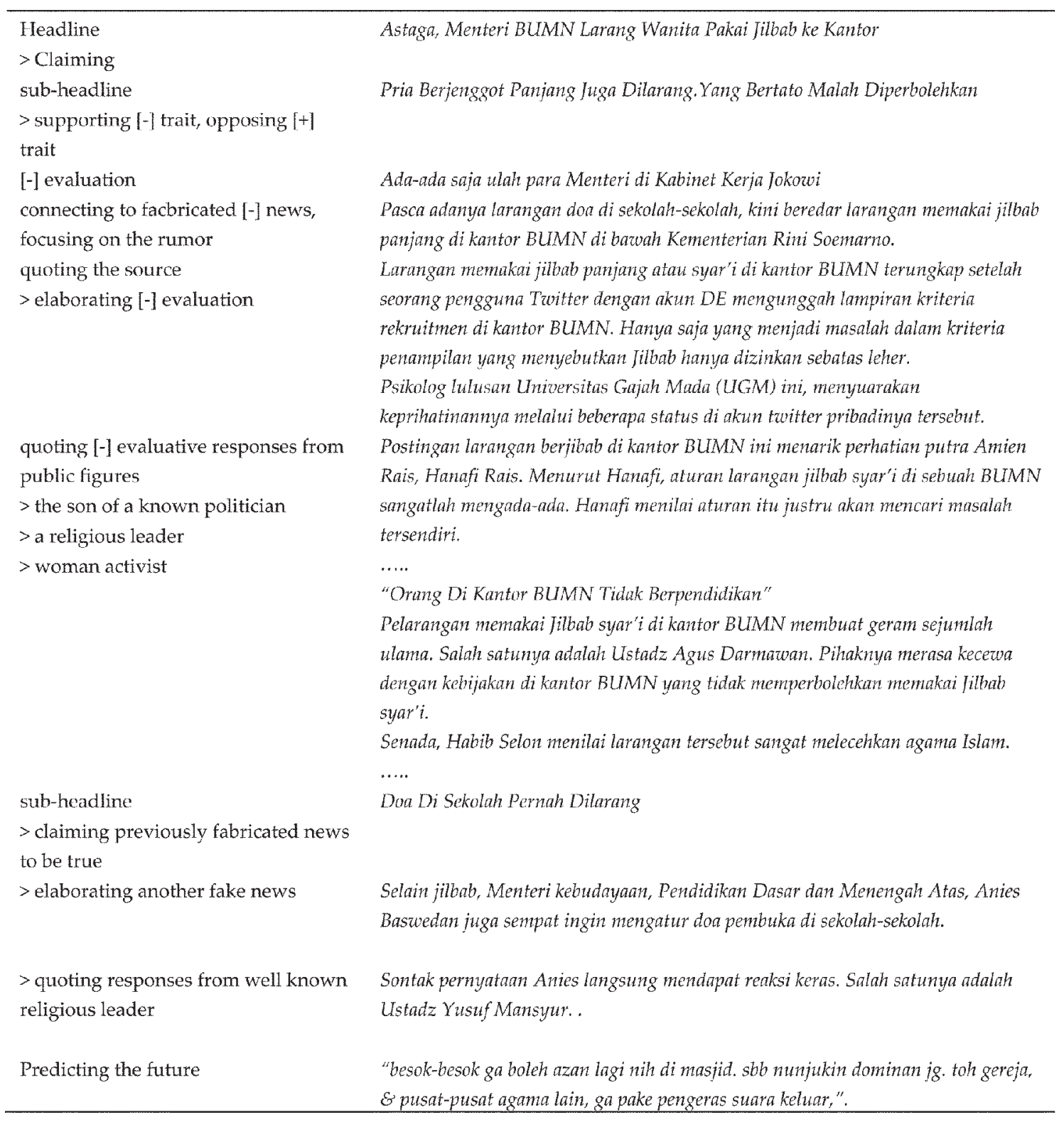

(25) Aktivis wanita dari NU Pusat, Yana Lathiva mengatakan, peraturan tersebut tidak relevan diterapkan di Indonesia yang masyarakatnya mayoritas beragama Islam.

A woman activist from NU, Yana Lathiya believed that the rule is not relevant to apply in Indonesia where the majority of the people are muslims.
(26) Salah satunya adalah Ustadz Yusuf Mansyur
One of them is Ustadz Yusuf Mansyur

The preference of proper names, and how they appear with title or addresses, is one crucial importance in the critical reading of a text (Hopper, 2014).

Proper names here are almost always followed by a title, for instance religious 
leader (such as ustadz and habib), to mark in-group (muslim) identity. Hanafi Rais, a politician, is described in two ways. First as the son of Amin Rais. Amin Rais was once the leader of Partai Amanat Nasional (PAN) one of the big and modern Islamic parties in Indonesia. Besides the son as a known politican, his position as a senator is also mentioned to amplify his role as a prominent figure. His complete name is mentioned here, Muhammad, to establish his Islamic identity.

In (25), the rumor has the support from a woman activist from NU (Nahdatul Ulama), which is a large Muslim society in Indonesia. DE's profession as a psychologist is also mentioned in (20). Readers may get the impression that this is an honest and professional statement. As a plus, it also mentions her academic background from UGM, one of the best universities in Indonesia.

Some words with negative evaluation are also addressed to RS or AB. These words are inherently negative, like melarang 'to forbid', konyol/ada-ada saja 'ridiculous', kecewa 'dissapointed'. Some other words are negated by explicit negative marker such as tidak boleh 'not allowed', tidak berpendidikan 'uneducated'. Some already negative evaluation words are even intensified such as sangat bodoh 'very stupid' and sangat mengada-ada 'very ridiculous'.

Each content ends with an evaluative prediction for the future, which is of course also negative; such as 'sooner the government will regulate the size of pants that you have to wear', 'call for prayers will be forbidden for muslim as Masjid (muslim prayer house) well as using loud speakers'.

The presence of the comments from prominent figures here makes narrative structure very convincing, but unfortunately used to support lies. In short, the discourse structure here has lead the readers to believe that government, as represented by the ministers (RS and $A B$ ), is anti-islam.

\section{CONCLUSION}

The series of DE's actions presented hereis exactly the same as 'test the water scenario'. DE proposed the BUMN recruitment issue to see how people respond to it. NS then took her tweets as a solid evidence (along with what DE claimed to be an assessment sheet for a BUMN recruitment test) for its headline without any confirmation either to the minister of BUMN or to DE (according to DE's claim).

Some readers, which got provoked to condemn the minister of BUMN, were driven by the anti-islam documents she uploaded. Under my evaluation, the document is very odd in terms of its discourse structure. The specific marking seemed to be unnatural or be by-design.

Up to now, DE cannot show the original version of the assessment sheet (if it does exist). Therefore, no wonder many doubt the originality of the document. Soon after the ministry officially refuted this issue, DE then claimed that NS and others who have condemned RS as the minister of BUMN have interpreted her tweets wrongly.

So what is the reason for this wrong generalization to take place? I believe that the wrong generalization is the effect that DE wanted. The linguistic configuration of her series of tweets, which I presented here, has shown that she shifted BUMN from indefinite noun to generic and she even widened the coverage not only to all BUMNs but also to all government institutions. It became more provocative as she also highlighted the acceptance of persons with negative traits (tattoo) instead of positive ones (good muslim traits).DE's clarification about her tweets is much about the details; that she never mentioned any name, that she never contacted NS. But of course the reference 
can easily be deduced exophorically. However, her inconsistency has shown that we deserve to question her intent and the authenticity of the document.

One issue that has to be explored further is about ideology. People with the same in-group identity as DE seemed to be easily provoked; they agreed to her tweets without any critical reading. It is possible that they follow DE's narrative design without careful investigation, as they fully believe of the person behind twitter account of DE who claimed sharing the same in-group identity. For this reason, we have to be careful in responding a news although it somehow 'attacks' our ideology. Being critical is a must, regardless of the media. We have witnessed how NS has failed to apply standard journalism ethics.

\section{ACKNOWLEDGEMENTS}

I thank the reviewers for useful comments and feedbacks that have significantly improved the quality of this paper. I also thank the journal managers, editor and staff for their patience and responsiveness during the correspondence while working on the manuscript. I also thank my colleague, Herudjati, Ph.D, for his expert advices during the discussion session. Special thanks to my wife and children for their patience when I was working on this self-funded research.

\section{REFERENCES}

Asmaramurthi, W. 2008. Tak and Kok in Javanese. Utrecht: Utrecht Institute of Linguistics.

Barker, J. 1999. “The Tattoo and the Fingerprint: Crime and Security in an Indonesian City". Doctoral Dissertation, Faculty of the Graduate School of Cornell University. Cornell: Cornell University.

Borah, P. 2011. “Conceptual Issues in Framing Theory: A Systematic Examination of a Decade's Literature". Journal of Communication, 61(2), 246-263.
Brown, P., \& Levinson, S.-C. 1987. Politness: Some Universals in Language Use. Cambridge: Cambridge University Press.

Caplan, J. 1997. Speaking Scars': the Tattoo in Popular Practice and Medico-Legal Debate in Nineteenth-Century Europe. In History Workshop Journal 44, 10742.

Carson, J. 2000. "The Semantics of Number in Malay Noun Phrases". Masters Thesis. Calgary: University of Calgary.

Center, C. L. 2003. Cambridge Dictionary of American Idioms. Cambridge: Cambridge University Press.

Chung, S. 2000. “On Reference to Kinds in Indonesian". Natural Language Semantics 8 (2), 157-171.

Crystal, D. 2006. Language and the Internet. Cambridge: Cambridge University Press.

Diaz, M.-A. 2011. “Manipulation of Teenagers Through Advertising: A Critical Discourse Approach." Revista de Lingüística y Lenguas Aplicadas, 6(1), 25-38.

Eckman, F.-R., Moravcsik, E.-A., \& Wirth, J.-R. 1986. Markedness. New York: Springer.

Fairclough, N. 2013. Critical Discourse Analysis: The Critical Study of Language. (2nd Edition). Amsterdam/Philadephia: Routledge.

Frost, C. 2014. Journalism Ethics and regulation. Philadelphia: Routledge.

Hopper, P. 2014. “The Emergence of Proper Names in Discourse". In H.-G. Davis, \& T.-J. Taylor, Redefining Linguistics (pp. 149-162). New York: Routledge.

Huang, Y. 2006. "Anaphora, Cataphora, Exophora, Logophoricity". In D. Crystal, Encyclopedia of Language \& Linguistics (Second Edition). New York: Elsevier Ltd.

Hurley, P. 2012. A Concise Introduction to Logic: 11th Edition. San Diego: Wadsworth Cengage Learning.

Jones, R. 2007. Loan-Words in Indonesian and Malay. Leiden: KITLV Press. 
Marchi, R. 2012. “With Facebook, Blogs, and Fake News, Teens Reject Journalistic 'Objectivity'”. Journal of Communication Inquiry, 36(3), 246-26.

Marcoci, S. 2014. “Some Typical Linguistic Features of English Newspaper Headlines". Linguistic and Philosophical Investigations, (13), 708-714.

Molinaro, N., Carreiras, M., \& Duñabeitia, J.-A. 2012. Semantic Combinatorial Processing of Non-anomalous Expressions. Neuroimage, 59(4), 3488-3501.

Porter, P.-H. 2005. What is Meaning: Fundamentals of Formal Semantics. New York: Blackwell Publishing.
Sinclair, J. 2003. Reading Concordance. London: Pearson \& Longman.

Tran, G.-Q. 2002. "Pragmatic and Discourse Markedness Hypothesis." Conference of the Australian Linguistic Society Available (pp. 98-109). Melbourne: Australian Linguistics Society.

Wijaya, D. 2012. “Teaching English Generic Nouns: The Exploration of The Generic Idea in English and Indonesian and The Applications of Explicit Instruction in Classroom". JELT Indonesia Vol 8 (2), 98-115. 